\title{
EUROSON 2017 Ljubljana, Slovenia
}

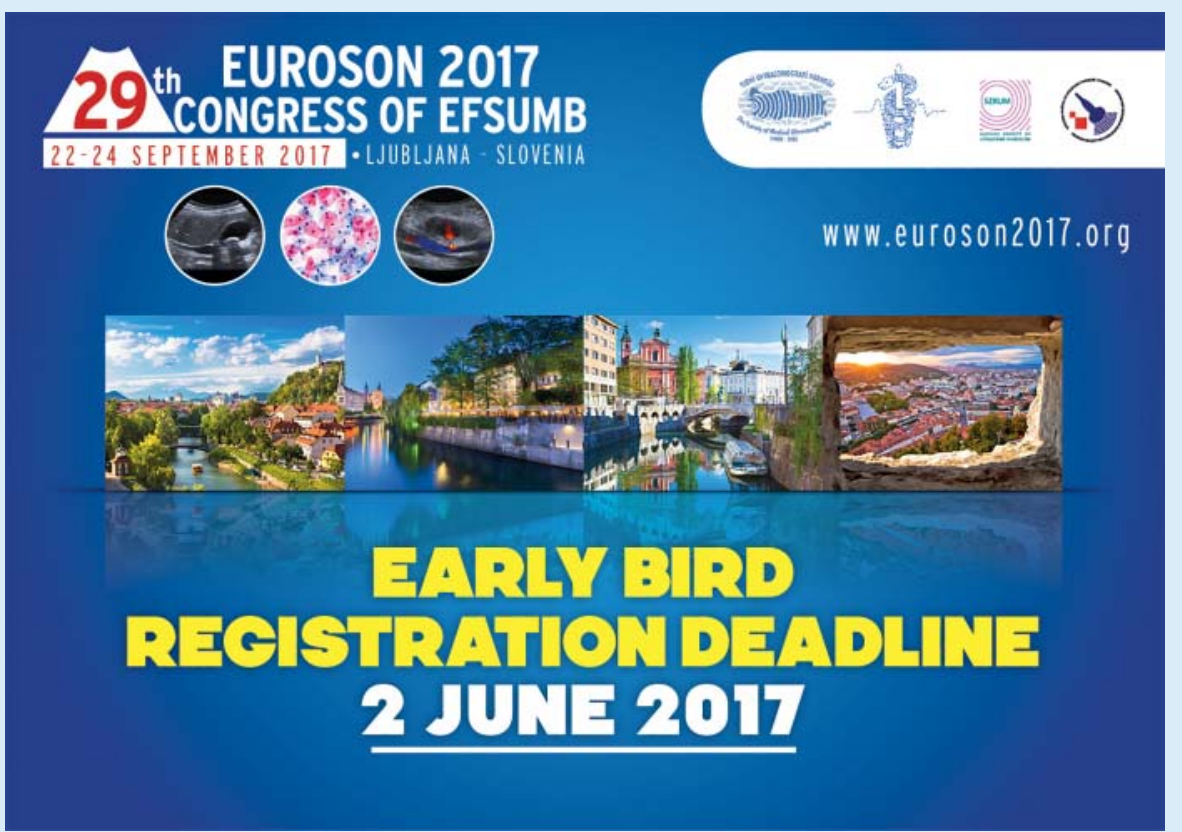

